University of Wollongong

Research Online

Faculty of Law, Humanities and the Arts Papers (Archive)

$1-1-2013$

\title{
Excavating the borders of literary anglo-saxonism in nineteenth-century
}

Britain and Australia

Louise D'Arcens

University of Wollongong, louised@uow.edu.au

Chris Jones

University of St Andrews

Follow this and additional works at: https://ro.uow.edu.au/lhapapers

Part of the Arts and Humanities Commons, and the Law Commons

Research Online is the open access institutional repository for the University of Wollongong. For further information contact the UOW Library: research-pubs@uow.edu.au 


\title{
Excavating the borders of literary anglo-saxonism in nineteenth-century Britain and Australia
}

\author{
Abstract \\ Comparing nineteenth-century British and Australian Anglo-Saxonist literature enables a "decentered" \\ exploration of Anglo-Saxonism's intersections with national, imperial, and colonial discourses, challenging \\ assumptions that this discourse was an uncritical vehicle of English nationalism and British manifest \\ destiny. Far from reflecting a stable imperial center, evocations of "ancient Englishness" in British \\ literature were polyvalent and self-contesting, while in Australian literature they offered a response to \\ colonization and emerging knowledge about the vast age of Indigenous Australian cultures. \\ Keywords \\ era2015 \\ Disciplines \\ Arts and Humanities | Law

\section{Publication Details} \\ D'Arcens, L. and Jones, C. (2013). Excavating the borders of literary anglo-saxonism in nineteenth-century \\ Britain and Australia. Representations, 121 (1), 85-106.
}




\section{LOUISE D'ARGENS AND CHRIS JONES}

\section{Excavating the Borders of Literary Anglo-Saxonism in Nineteenth-Century Britain and Australia}

Anglo-Saxonism is Hardly a thing of the past. Nothing demonstrates this so potently as the media response to the 2009 discovery of a spectacular hoard of Anglo-Saxon objects by an amateur treasure hunter running his metal detector over a field in Staffordshire, England. This excitement is understandable: apart from the beauty of these objects, here is an irresistible story of how the Anglo-Saxon past is still with us-just there, under the topsoil, if we only look-and yet also vulnerable to loss, uncovered only by chance. This media response has been accompanied by a chorus of scholarly opinion proclaiming the hoard's immeasurable historical value, deemed even greater than the Sutton Hoo ship burial, and relishing the unprecedented insight it promises into early medieval English life.

This popular excitement has had its scholarly counterpart over the past decade in a surge in the study of medievalism-the postmedieval, imaginative reconstruction of the Middle Ages-by scholars originally trained in traditional medieval studies. These scholars have engaged in reflexive analysis of the cultural assumptions underlying medievalist research, and in a rigorous anatomization of how the Middle Ages have signified for, and intersected with, later periods up to the present. The developing dialogue between medievalism studies and critical work on nationalism, race, and cultural memory has enabled the study of Anglo-Saxonism to make inroads into uncovering the ways in which the "Anglo-Saxon period" has been variously constructed by philologists, creative writers, antiquarians, and

\footnotetext{
A B S T R A C T Comparing nineteenth-century British and Australian Anglo-Saxonist literature enables a "decentered" exploration of Anglo-Saxonism's intersections with national, imperial, and colonial discourses, challenging assumptions that this discourse was an uncritical vehicle of English nationalism and British manifest destiny. Far from reflecting a stable imperial center, evocations of "ancient Englishness" in British literature were polyvalent and self-contesting, while in Australian literature they offered a response to colonization and emerging knowledge about the vast age of Indigenous Australian cultures. RePRESENTATions 121. Winter 2013 (c) The Regents of the University of California. ISSN 0734-6018, electronic ISSN 1533-855X, pages 85-106. All rights reserved. Direct requests for permission to photocopy or reproduce article content to the University of California Press at http://www. ucpressjournals.com/reprintinfo.asp. DOI: 10.1525/rep.2013.121.1.85.
} 
archaeologists and how it has functioned as a repository of linguistic and material artifacts that reflects "pure" Englishness. Intrinsic to this work is an analysis of how interest in the Anglo-Saxon past has underpinned a wide range of cultural, racial, and political projects.

Of the work examining nineteenth-century Anglo-Saxonism, much has been focused on Britain, and in particular on England, looking at philological and antiquarian efforts to secure deep local linguistic and material traditions and a notion of "native" Englishness. It is now a commonplace to acknowledge nineteenth-century Anglo-Saxonism's implication within what John M. Graham has described as a "philological arms race" that ghosted the tensions between England and her European neighbors throughout this period. ${ }^{1}$ Some work has also examined the relationship between Anglo-Saxonism and imperialism, including a major study of American Anglo-Saxonism. ${ }^{2}$ This has expanded the geographical frame of reference, but the ideological emphasis has continued to be weighted toward exploring Anglo-Saxonism as a vehicle of such grandiose and triumphalist ideologies as British imperial manifest destiny and white racial supremacy. Relatively little consideration has been given to the more complex intersection of Anglo-Saxonist discourse with the haphazard exigencies of colonial settlement, or to the surprising ways in which it has been pressed into the service of describing the cross-cultural and multitemporal nature of colonial cohabitation.

We wish to "decenter" Anglo-Saxonism's major received narratives by offering a comparative analysis of the related but distinct traditions of nineteenth-century British and Australian literature. By bringing some destabilizing examples from the better-known British literary tradition into dialogue with examples from the sizeable but virtually unknown corpus of Australian Anglo-Saxonist literature, we aim to expand both the geographical and the cultural-ideological map of Anglo-Saxonism in nineteenthcentury "greater Britain," thus enabling a more comprehensive and nuanced exploration of its intersections with national, imperial, and colonial discourses. We will argue that while some Australian poets appropriated Anglo-Saxonist tropes to situate the colonization of Australia within the longer history of English manifest destiny, others used these same tropes to bypass Britishness, creating a kind of anti-imperial Australian AngloSaxonism. We will also explore how poetic evocations of "ancient Englishness" in late nineteenth-century Australia responded to emerging knowledge about the vastly greater age of Indigenous Australian cultures and examine the kind of poetry produced from this crucible of competing antiquarianisms.

Far from suggesting that this decentering of Anglo-Saxonism took place only at the borders of the British Empire, we also challenge the notion of 
British Anglo-Saxonism as the expression of a stable imperial center by focusing on the roles of Scottish and provincial English writers in developing some of the most influential models of Anglo-Saxonism. Because Scotland, a major exporter of Anglo-Saxonism around the globe, was itself both margin and center, colony and colonizer, the "source" of nineteenthcentury Anglo-Saxonism can be seen to be divided, polyvalent, and selfcontesting, while the categories "native" and "alien" were already highly tractable even before they traveled to the antipodes. Complementing this Scottish Anglo-Saxonism, the Anglo-Saxonism produced at England's southern periphery disturbed the centrist, metropolitan cultural map of Greater Britain even when it appeared to affirm it. This emphasis on Scottish and provincial Anglo-Saxonism leads us to argue for Anglo-Saxonism as a border discourse: "border" in the sense that it is inflected by its emergence out of British border territories with their history of historical contestation and cohabitation, and "border" in the sense that it is arguably at its most strained, but also its most arresting, when it enters contexts where cultures and ethnic groups border one another uneasily. Rather than being liminal or exceptional, these strained examples of Anglo-Saxonism aptly capture this discourse's negotiation of a range of porous borders-temporal, geographical, and racial.

Of particular interest in this nineteenth-century "border Anglo-Saxonism" is its often-revealing use of the metaphors of excavation, in particular its telling figuration of Anglo-Saxon, Anglo-Scottish, and Anglo-Australian pasts through images of remains, artifacts, and fossils. These metaphors are, most conspicuously, an index of Anglo-Saxonist literature's engagement with formative nineteenth-century ideologies of national and imperial destiny, ethnic purity and impurity, and cultural cohabitation; but this excavational aesthetic is also an apt expression of the multilayered materiality of contested and coinhabited soil-what is found both in it and on it. As such, a treatment of these motifs consolidates the shift away from the received emphasis on Anglo-Saxonism's relationship to the abstractions of nation and empire, to the examination of its engagement with the intimacies of earth.

Nineteenth-century British Anglo-Saxonism's engagement with borders is evident in one of its earliest texts: Walter Scott's Ivanhoe (1819), which was wildly successful at inserting into the popular imagination the notion of the Saxons as proto-English in a previously unprecedented way. ${ }^{3}$ In many ways Ivanhoe sets an agenda for Anglo-Saxonism that was either followed or challenged, but never ignored, for much of the rest of the century. We turn to it first because the Saxonist literary precedent it sets reveals that the nineteenth-century philological and antiquarian pursuit of "pure" Saxon England was much less stable and less determined in its originary phase than current criticism allows. 
Scott aimed to write a romance about the forging of a stable sense of English national consciousness out of diverse and competitive ethnic groups in the late twelfth century. In this imaging of history the Saxons are depicted as natives, a withered cultural root in need of reinvigoration by contact with and assimilation to other groups, chiefly the Normans, but nevertheless also as part of an unbroken continuous tradition; they are the origin of Englishness. We first encounter two of the novel's Saxons, the swineherd Gurth and the jester Wamba, in a forest, a setting that recalls the unspoilt primeval Wald of Teutonic myth, and which is the natural habitat of the Germanic urEnglish. This opening sequence, however, actually disturbs the myth of $u$ rEnglishness, challenging the very idea of a stable period of native belonging:

The sun was setting upon one of the rich grassy glades of that forest.... Hundreds of broad-headed, short-stemmed, wide-branched oaks, which had witnessed perhaps the stately march of the Roman soldiery, flung their gnarled arms over a thick carpet of the most delicious green sward;... A considerable open space, in the midst of this glade, seemed formerly to have been dedicated to the rites of Druidical superstition; for, on the summit of a hillock, so regular as to seem artificial, there still remained part of a circle of rough unhewn stones, of large dimensions. Seven stood upright; the rest had been dislodged from their places, probably by the zeal of some convert to Christianity, and lay, some prostrate near their former site, and others on the side of the hill. One large stone only had found its way to the bottom, and in stopping the course of a small brook, which glided smoothly round the foot of the eminence, gave, by its opposition, a feeble voice of murmur to the placid and elsewhere silent streamlet. ${ }^{4}$

Although ostensibly introducing us to the indigenous English Saxons, this description first points insistently to a much deeper, earlier past. Throughout the novel Wamba, Gurth, and their fellow Saxons speak and act from their belief that they have ancestral rights to this land, and that the Normans are encroaching imperialist incomers. Yet the reference to Druidical stones, on one of which the Saxons are symbolically sitting, forcibly remind us of the British Celtic cultures that preexisted the Anglo-Saxons in the Atlantic archipelago, and which have a prior claim to aboriginal status. Scott wishes us not to forget that these Saxons were themselves once an occupying power, a migrant people, like the invading Romans, whose soldier ghosts are also conjured into this scene. Both the harmonious idyllic setting, and the ease with which the claim "native" might be made, are therefore already twice disturbed by the narrative voice from the novel's very beginning.

Moreover, the narrator tells us that these standing stones were probably dislodged by zealous Christian converts. The novel therefore interposes another wave of historical agents who change what England is and means, altering the course of something as seemingly integral to the landscape as 
a stream. Significantly, it is only here, at the site of cultural conflict, that the landscape is set into articulation ("a feeble voice of murmur"); where, uncontested, it gives no voice. Those converts (whether Celtic British or Romano-British is unclear), although latecomers to the forest relative to the Druids and Roman soldiery, predate the "native" Saxon characters, perched on the effects of their labors, by some centuries. The novel's opening scene works to set up a symbolic physical displacement in the landscape and a pattern of population displacement over time. In view of this this trope of displacement it might not be too fanciful to read the mixed composition of the forest (primarily oak, but punctuated with other species) as being part of this wider motif of the already-hybridized primeval or "ur." Within this passage, the Anglo-Saxon past both disturbs and is disturbed by a deeper past. In turn, this scene, focalizing our sense of deep historical awareness, is itself the backdrop to the literal disturbance of the forest peace by a mixed group of French Norman monks, a Templar, and a Saracen train, arriving a few paragraphs later. ${ }^{5}$

Scott's own sense of belonging may well be pertinent to his writing of the Saxons. Not a Gaelic highlander, but a pro-Union, lowland, Tory Scot, Ivanhoe's author made his home, Abbotsford, in the Borders, just outside Melrose. ${ }^{6}$ Melrose Abbey, whose dramatic ruins attracted Scott to the area, owes its own existence at that site to an earlier monastic community founded at nearby Old Melrose by representatives of the Irish church operating out of Lindisfarne (probably in the seventh century, under the guidance of Saint Aidan), in what was then the ("Anglo-Saxon") Anglian kingdom of Northumbria, which had established itself by supplanting the preexisting British, as lamented in the medieval Welsh poem $Y$ Gododdin. ${ }^{7}$ By Scott's time the present abbey, reestablished for the Cistercians in the twelfth century by Kind David I of Scotland (and daughter house to Rievaulx, Yorkshire), found itself on the Scottish side of a political border that had been considerably less stable than the somewhat migratory course of the river Tweed that marked that porous boundary, and part of a stateless nation that had found itself-by a union first of crowns and then of parliaments-part of a Greater Britain and then a world empire. Scott deliberately chose to root himself, therefore, at the site of a complex pattern of cultural change, displacement, and overwriting. It could even be said that he himself marks the place of the Anglo-Saxon within Scotland within Britain within an Empire.

In writing about medieval England, Scott was also partly writing a proleptic allegory of Union, and of the need to strengthen cultural assimilation in the long after- shadow of Jacobite rebellion. At this allegorical level we come across an interesting complication of what Anglo-Saxon "means" in Scott's narrative. For in the introductory chapter Gurth is explicitly likened in dress to a Scottish Highlander. ${ }^{8}$ The "native" Saxon is thus correlated 
with the recently troublesome and hostile "natives" of the Scottish highlands, who have also been assimilated within a larger national framework. This collocation amplifies one of the themes set out in the framing prefatory epistle by the fictional antiquarian Laurence Templeton: "It was not above sixty or seventy years, you observed, since the whole north of Scotland was under a state of government nearly as simple and as patriarchal as those of our good allies the Mohawks and Iroquois." "It had become a common trope among antiquarians to liken the Anglo-Saxons to so-called primitive tribes native to various parts of the British Empire, as Scott collocates them here with Scottish Highlanders and Aboriginal Canadians. Thomas Percy had likened the oral literature of the Saxons to that of the Amerindians, for example, and Sharon Turner, whose History of the Anglo-Saxons Scott knew and drew on, likened the New Zealand Maori to the migration period AngloSaxons. ${ }^{10}$ It was in effect a topos by which the nineteenth-century British reminded themselves that they too had been the "primitive," the "uncivilized" and colonized "Other," and in need of a civilizing (even if violent) catalyst, such as the Norman Conquest had been. ${ }^{11}$

Templeton's epistle goes on to suggest that the closer proximity of Scotland to its primitive or ancestral past is advantageous to the historian:

The Scottish magician, you said, was like Lucan's witch, at liberty to walk over the recent field of battle, and to select for the subject of resuscitation by his sorceries, a body whose limbs had recently quivered with existence, and whose throat had but just uttered the last note of agony.... The English author, on the other hand, can, only have the liberty of selecting his subject amidst the dust of antiquity, where nothing was to be found but dry, sapless, mouldering, and disjointed bones. ${ }^{12}$

In Scotland then, this primitive or aboriginal past is nearer to the surface of the present than is the case in England; it requires less excavation. The historian of England must deal in fossils but can learn something about the quality of the primitive past from his Scottish counterpart. In Templeton's argument, as well as Scott's novel, as its earliest reviewers noted, Scotland can teach England the forms of its Anglo-Saxonism. ${ }^{13}$ Thus the notion of an Anglo-Saxon origin is already knowingly self-conflicted even in the major $u r-$ text of Anglo-Saxonism, and authorized by its own margins. What Ivanhoe teaches us is that Anglo-Saxonism was from the first a border discourse: that "abroad" and "alien" were always built into its terms of internal operation, even before it traveled abroad.

This dimension of Scott's scene setting has been downplayed in a tendency to emphasize instead Ivanhoe's influence on that form of nineteenthcentury Anglo-Saxonism strongly associated with linguistic and ideological chauvinism (and which naturally drew inspiration from the famous exchange between Gurth and Wamba on linguistic politics in the novel's 
opening chapter). ${ }^{14}$ The restoration of the border legacy bequeathed by his novel allows for the correction of some key distortions within the current received narrative. First, it reveals that those nineteenth-century advocates of Anglo-Saxon purity hitherto taken to be heirs of Ivanhoe's AngloSaxonism were in fact actively denying and displacing its historical vision of British cultural impurity. Furthermore, in a versatile converse movement, a sensitivity to Anglo-Saxonism's negotiation of borders also allows us to detect the surprising, destabilizing elements that can be found even in those works that appear the epitome of purist Anglo-Saxonism.

A revealing case study can be found in the poetry and philological writings of William Barnes. Barnes is in many respects exemplary of the antiquarian desire to identify contemporary Englishness as having evolved organically from an Anglo-Saxon origin with which it remains in unbroken and living continuity. ${ }^{15}$ Barnes's location of withered yet surviving roots in England's linguistic soil differs notably from Scott's hybrid fossil-strewn landscape; for Barnes the longevity of an Englishness that could claim more than a millennium of continued history legitimized its cultural superiority. In the course of enforcing this vision, however, he engaged in a striking reorientation of the parameters of nineteenth-century Anglo-Saxonist cultural geography.

Throughout his career Barnes produced a steady stream of articles and books on philology that repeatedly insisted on the desirability of English being spoken and written in its "pure" form, without recourse to foreign loan words, and with a morphology as close to that of Anglo-Saxon as possible. To the modern reader linguistic patriotism in this work might sometimes seem to shade into chauvinism, as in this article from the Gentleman's Magazine in 1832:

I wish Dr. Bosworth every success with his Anglo-Saxon Grammar. A more common cultivation of the Gothic tongues would tend, I think, to check the growing corruptions of our own; by showing how it may be enriched from itself, and therefore how little need we have of borrowing from Greek and Latin. ${ }^{16}$

Barnes goes on in the same article to advocate the use of "English" words (that is, those with Anglo-Saxon roots) such as "yearly" and "underground" over borrowings such as "annual" and "subterranean." He also argued for the resuscitation of defunct "native" patterns of compounding, as preferable to those of imported compounds, noting that "lorn, as we have it in lovelorn, is a participle of the old Saxon verb to lose," and might be made productive in new coinings, such as "waylorn" and "glorylorn." $\mathrm{He}$ finishes his article by remarking:

The English are a great nation; and as an Englishman I am sorry that we have not a language of our own; but that whenever we happen to conceive a thought above that of a plough-boy, or produce anything beyond a pitch-fork, we are obliged to 
borrow a word from others before we can utter it, or give it a name; and to conclude, as the English language is most rich in literature of every kind, our writers should aim to purify and fix it, for, if they go on corrupting it, their own writings, after some time, will not be read without a glossary, perhaps not at all.

This passage exposes the complexity of Barnes's excavational aesthetic: for despite his famed enthusiasm for reinvigorating linguistic "roots and stems," his images of primitive soil-working here underline a rejection of the popular association of native English with crude earthiness. Ironically, in light of his concluding words, it is Barnes's poems that are now ubiquitously published with a glossary, an apparatus that he began to supply during his own lifetime. While Barnes wished to fashion his poems from an English that affirmed its uninterrupted continuity from "Saxon-English," supplementing them with glossaries actually exposed the discontinuity and distance between the putative root and present outgrowth of English. ${ }^{17}$

Ten years after the Gentleman's Magazine article, in the preface to an English grammar book aimed at schoolchildren, and based on the ideals of linguistic purity he had earlier articulated, we find Barnes linking freedom from foreign linguistic borrowings to political freedom and self-determination, identifying these with an Anglo-Germanic ethnicity disseminating itself globally:

The Author of this little Grammar thinks it right to state the principles upon which he has written it. He is one of a class, and he hopes a large class, of Englishmen who, from a study of the Anglo-Saxon and other Gothic tongues ... or from the pride of belonging to a branch of that bold and great race of mankind whose kindred are treading on free ground from Iceland to Australia, and from Austria to America, have conceived a wish that the Saxon body of the English language should be better understood, so that it might not be further corrupted if it cannot be enriched from its own Gothic resources. ${ }^{18}$

Here the assumed moral superiority of "pure" languages is made an explicit reflex of political superiority. In his formulation of this doxa Barnes emphasizes a pan-Germanic manifest destiny; for other writers the pedigree of an English that could trace its roots back to the migrating fifth-century German tribes of the North Sea basin was an analogue of the ascendancy more specifically of a greater England projected through the agency of Great Britain in the form of the British Empire. ${ }^{19}$

By the end of Barnes's long career he was publishing grammars and textbooks written in the very "self-enriching," "pure" Saxon-inspired English he had been propounding. In his 1878 An Outline of English Speech-Craft (grammar) and his 1880 An Outline of Rede-Craft (Logic) with English Wording, Barnes talks not of letters but "speech-tokens," describes polysyllabic words as "many-sounded," replaces the word "science" with "lore," refers to abstract 
nouns as "unmatterly thing-names" and intransitive verbs as "unoutreaching time-taking-words." ${ }^{20} \mathrm{He}$ was also still arguing for nonproductive AngloSaxon compound elements to be revived; his major example in Rede-Craft was based on the suffix "-some" ("barksome" dogs being different to barking dogs, just as quarreling and quarrelsome are not synonymous) ${ }^{21}$

These linguistic attitudes find their way into Barnes's poems, so that one is hard pressed to find in them a word not derived from Anglo-Saxon. Barnes the poet takes the advice of Barnes the philologist, making liberal use of a range of self-enriching compounds from Saxon elements, "-some" being one of his favorites, evidenced by "worksome" and "tiresome" in the poem "Thissledown," and by "darksome" in several poems, including "Liady-Day an' ridden House," "The Lilac," and "Home from a Journey." ${ }^{22}$ Barnes is also fond of prefixing the participle with "a-," as in "a-springèn," "a-turnèn" ("My Orchet in Linden Lea"), "a-spreadèn," "a-dried," "a-leävèn," "a-lost," "a-talkèn," "a-wandrèn" ("Woak Hill") ${ }^{23}$ Morphological features such as these have tended to be treated as characteristic of his Dorsetshire dialect, but Barnes thought them to be linguistic survivals from Anglo-Saxon. ${ }^{24} \mathrm{He}$ valued his local dialect, not merely for reasons of personal attachment, or because it possessed rural authenticity, but because he believed:

This dialect, which is purer and more regular than that which has been adopted as the national speech, is, I think, with little variation, that of most of those western parts of England which were included in the kingdom of the West Saxons, and has come down by independent descent from the Saxon dialect which our forefathers, the followers of Cerdic and Cynric, Porta, Stuf, and Wihtgar, brought from the South of Denmark, and the Saxon islands Nordstrand, Busen, and Heiligöland. ${ }^{25}$

Barnes's Dorsetshire poems were, then, for him, Anglo-Saxon poems; it this claim that renders them instances of border Anglo-Saxonism. For in Barnes's particular formulation, in order to insist on the continuity of Englishness, he has to champion a form of border or provincial English over that of Standard or "national" English. If not quite making a margin the center, he looks to what many would have regarded as a rural backwater as the preferred benchmark of Englishness. Although this is motivated, of course, by a strong sense of regional patriotism, nevertheless it is noteworthy that even in a "classic" deployment of Anglo-Saxonism such as Barnes's, keen to intersect itself with the discourse of British imperialist justification, the local validates the metropolitan; a literal "little England" authenticates a greater Britain, and the provincials are made the true indigenous natives.

The nineteenth century in Australia did not have any straightforward equivalent to a figure such as Barnes. It was not until the early twentieth century that the Australian expatriate composer and ethnomusicologist Percy Grainger devised the eccentric Barnes-esque "blue-eyed English" that 
we find peppered throughout his correspondence and musical scores. ${ }^{26}$ The emphasis in colonial Australia was on racial-behavioral rather than linguistic continuities between the present and the Anglo-Saxon past. In particular, the expansionism of the imperial age, as historical proof of English greatness, was presented as an atavistic expression of the will-toinvasion attributed variously (or collectively) to Anglo-Australians' Saxon, Viking, and Norman forebears. This loosely construed Anglo-Saxonism brought a deep historical complexion to racially inflected English triumphalism in colonial Australia. A 1907 article in the Sydney journal the Lone Hand, to take just one late example, attributed the English occupation of Australia not to political or economic ambition, or to penal expediency, but rather to "that roving instinct which bespeaks the unconquerable Norse element in the British blood." ${ }^{27}$ As with English Anglo-Saxonist discourse, the Australian notion of seafaring English "Norseness" was subject to a range of inflections; but all instances of English greatness across the centuries were understood to have emerged as a result of it.

This use of Anglo-Saxonism as a discourse of British manifest destiny was hardly unique to nineteenth-century Australia. So what did Australians do with this legacy that was distinct from the English and Americans? Donald Cole has argued that Victorian and Edwardian explorations of AngloAustralian kinship "lapsed easily into Anglo-Saxonism with scarcely a local twist." 28 Looking at the bulk of Anglo-Saxonist verse, most of which appeared in periodicals throughout metropolitan and regional Australia, there is some basis to this claim. But Cole's assertion of unalloyed imitation is disturbed when we unearth examples of Anglo-Saxonist triumphalism that attempt to adapt it to the particular circumstances experienced within colonial environments. Looking at these more complex examples, we see that mythologies celebrating English continuity were placed under considerable discursive strain when used to characterize life in the colonies.

One conspicuous example of this can be found in Rolf Boldrewood's novels of the 1880s and '90s such as A Sydney-Side Saxon (1894), in which he portrays landowning settlers as latter-day colonial Anglo-Normans. In its uneasy disavowal of Aboriginal dispossession and its narrative, which courts miscegenation only to ward it off (the "Saxon" settler Jesse almost marries a "half-caste" Aboriginal woman), A Sydney-Side Saxon's apparently blithe assertion of an ancient English instinct for land occupation labors under a myriad of barely acknowledged anxieties about colonial cohabitation and the racial destinies of settlers and indigenes. ${ }^{29}$ Boldrewood's novels disclose the pressures placed on Anglo-Saxonist migration myths once they moved from the open seas to the shores of a land whose great age and ancient Indigenous cultures threw into relief the relative youth of the settler culture despite its attempt to narrate itself within a deep English past. 
This creation of an ancestral complexion for settler society was extended into the field of cultural endeavor, and in particular into literature. As in England, the desire to locate and animate a deep Anglophone poetic tradition is clearly evident in late nineteenth-century Australian literature, as well as in early commentaries on that literature. But, unlike its English counterparts, this fascination with tradition was not directed toward philological exactitude or etymological finesse. The excavational impulse and historical self-consciousness of nineteenth-century Australian poetry took another, quite idiosyncratic, form that took up the central tropes of Anglo-Saxonist poetic recovery and displaced them into the time frame of the present. In a move that clearly demonstrates the plasticity of Anglo-Saxonism in its border iteration, Australian poets did not present themselves so much as excavating ancient "native" relics of a linguistic or poetic past as actually being those native relics. Their perception that together they were founding Australian poetry meant that they presented themselves less as inheritors of a long Anglo-Saxon tradition and more as the Anglo-Saxons of Australia's future, with their verse being the ancestral verse that has not yet been buried. Colonial writers' sense that Australian settler culture lacked the historical depth of older European societies meant that the main historicizing gesture available to them was one in which they looked ahead to a distant Australian future when their own time would be regarded as a legendary chapter in the national story and their writings as the $u r$-texts of a glorious literary tradition to come.

The proleptically historical self-understanding of Australian colonial literature is nowhere more apparent than in the collective construction of the poetic persona of Adam Lindsay Gordon (1834-70), author of the verse collections Sea Spray and Smoke Drift and Bush Ballads and Galloping Rhymes. The poetic canonization of Gordon has a distinct, though sometimes oblique, Anglo-Saxonist complexion. Henry Kendall's elegy "The Late Mr. A. L. Gordon: In Memoriam," written within a week of the poet's suicide in 1870, was the first of many portraits of Gordon that developed his persona as settler-Australia's ur-poet. In this poem Kendall describes Gordon as the singer of "the first great songs these lands can claim / To be their own," placing him within an ancient bardic tradition. He is:

The bard, the scholar, and the man who lived

That frank, that open-hearted life which keeps

The splendid fire of English chivalry

From dying out. ${ }^{30}$

The use of the word "bard," while seemingly Celtic in its reference, has a surprisingly solid Anglo-Saxonist pedigree within highly influential eighteenth- and nineteenth-century discussions of Anglo-Saxon poetry. From 
antiquarian treatments such as Thomas Percy's Reliques of Ancient English Poetry (1765) and Thomas Warton's A History of English Poetry (1774), through to more professionalized historical accounts such as Sharon Turner's History of the Anglo-Saxons (1807), and John Josias Conybeare's Illustrations of Anglo-Saxon Poetry (1826), we find Anglo-Saxon poets referred to as a bard interchangeably with, or in place of, the Saxon word scop. ${ }^{31}$ Whether or not Kendall was aware of this linguistic pedigree, his description of his contemporary Gordon as a "bard," while partly acknowledging Gordon's Scottish birth, also performatively Anglo-Saxonizes him insofar as it portrays him as a primitive ancestral figure in an Anglo-Australian vernacular poetic tradition to come. Just as the creators of Anglo-Saxon literature were believed to have spawned the illustrious national traditions of medieval England, so too Gordon sings Australia's "first great songs."

We can detect a comparable impulse among a number of others who have aimed to defend Gordon's right to the title of Australia's first poet. A fascinating and complex case in point can be found in the commentary of Frank Maldon Robb, in the closing paragraph of the introduction to his edition of The Poems of Adam Lindsay Gordon (first edition 1912), entitled "Australia's Debt to Gordon." Robb renders Gordon "ancestral” by projecting forward several hundred years to a time when the poet's tomb will be one of the nation's august ruins:

Centuries hence, when men go up beside the banks of the noble stream of great poetry, which we believe will one day gladden the city and humanize and fertilize and deepen our Australian national life, as they climb reverently to its source, they will find on a broken memorial column, in letters that cannot fade, the name of ADAM LINDSAY GORDON. ${ }^{32}$

Robb's imaginary projection of Gordon as future ancestral poet-and as future fossil fragment-here echoes verbally the visual message Gordon's early followers aimed to convey when they commissioned the monument above his grave in Brighton Cemetery, Melbourne. Apparently not content to leave Gordon's ancestral status to evolve over the coming centuries, these devotees organized to mark his grave with a broken stone column. While the broken column clearly symbolized Gordon's premature death, its unmistakable evocation of the ruins of former civilizations also had the effect of endowing the poet, less than twenty years after his death, with instant ancestral gravitas. Of course, there is no denying the classical, rather than Saxon, flavor of a laurel-wreathed broken Doric column. But the desire to memorialize Gordon in this way echoed, in Australian terms, the frenzied pursuit among the Anglo-Saxonists of nineteenth-century England to locate verse that could give credence to their nation's claim to an ancient vernacular poetic tradition. In recent years, as indicated in our introduction, a wealth 
of excellent work has examined the ideological potency of Anglo-Saxon literature for nineteenth-century scholars and antiquarians, who regarded it as the fountainhead and authentic expression of national culture. In a parallel gesture, Gordon's promoters endowed Gordon with the primal authenticity attributed to the Anglo-Saxon poets.

Nor did this motif die with the nineteenth century. In 1934 we find yet another example in a remark by French professor A. R. Chisholm in his foreword to a study of the Australian symbolist poet Christopher Brennan. Here, however, the Anglo-Saxon allusion is unambiguously pejorative. The most withering condemnation Chisholm can muster for what he regards as the "childishly anti-intellectual" local verse emerging from the nineteenthcentury "cult of the stockrider, the wattle and the bell-bird" is to describe it as "the Beowulf stage" of Australian "poesy." 33 Only the Francophilic sophistication of Brennan and his ilk can forge a path out of this cul-desac of primitive nationalistic versifying. Chisholm's evaluation of AngloSaxon literature is, furthermore, corroborated, however inadvertently, in a comment made in 1935 by nationalist literary critic P. R. Stephensen. Echoing the Spenserian assessment of Chaucer, Stephensen asserted of Australian poetry, "We are on the threshold of Australian selfconsciousness, at the point of developing Australian nationality, and with it Australian culture [;] we are in our Chaucerian phrase." ${ }^{34}$ For Stephensen, Chaucer's quest to elevate the national vernacular into a legitimately literary tongue was, in David Matthews's words, "an authentic medieval moment" that was being repeated in the early twentieth century in the new national environment of Australia. ${ }^{35}$ Together Chisholm's and Stephensen's remarks reveal that the gesture of portraying the Australian present as a medieval moment in the nation's literary evolution-a vigorous tradition in the making-continued to have an undeniable rhetorical appeal. But by the twentieth century it is clear that the Anglo-Saxon has come to be regarded as primitive, a period to be transcended, while the Chaucerian period represents a golden age of national self-confidence in which cosmopolitan sophistication combines with local pride to create a proud, distinctive literature and culture.

Despite the persistence of this impulse to engage in futuristic retrospection, the historical and ideological investments of this practice had in fact been satirized wickedly decades before Chisholm's and Stephensen's statements, in the 1897 poem "An Australian Mummy" by Irish-Australian poet Victor Daley. ${ }^{36}$ Now largely forgotten, Daley was, as his biographer Frank Molloy has recently reminded us, a widely known figure in his own time, and his work was held in high regard, especially within the metropolitan bohemian cliques of Sydney and Melbourne. ${ }^{37}$ Although Daley was and is best known for his lyric verse, he was also in the 1880s and 90s a chief writer for 
the Bulletin, a weekly newspaper founded in 1880 as the primary press organ for federationist, anti-imperial, and pro-Labor sentiment. In this capacity he was a prolific writer of mostly satirical topical verse, of which "An Australian Mummy" (published in the Bulletin on 21 August 1897) is an example. This very odd, probably hastily penned, but quite remarkable poem demands our attention for the way its description of colonial Australian society relies on, yet simultaneously lampoons, the nostalgic Anglo-Saxonist impulse of nineteenth-century antiquarianism. It is singled out here because it is also a consummate example of border Anglo-Saxonism, not only in the sense that its Anglo-Saxonism is brought into idiosyncratic dialogue with other temporal discourses circulating in colonial Australia, including Aboriginal archaeology, but also in the sense that the excavational metaphor on which it is premised discloses the ideological stakes of applying the archaeological discourses of English poetic philology to the contentious historical scene of colonial Australia.

The poem's premise is an ingenious one. Apparently produced three thousand years in the future (according to its prose prologue, which is in the form of an extract from a newspaper article written in the year 4897), the poem purports to be verses written by a leading Australian poet of the fifth millennium, Alexander W. Mudlarque, in response to the recent excavation of a mummy of "some person of note" that had been buried in "the ancient city of Melbourne" in 1897. Gazing upon and addressing himself to the mummy, which is now housed in the Museum of Antiquities, Mudlarque is drawn into a historical reverie in which he pictures life at "the dawn / Of Austral history-the Age of Gold" - a comic historical pun that Daley's readers would have identified as boomtime Melbourne in the wake of the midcentury gold rushes. As will be now be clear, this trope of futuristic nostalgia for the present, for all its strangeness, was a widely used response to the desire for historical imagination in a culture that perceived itself to be at the beginning of its history. One would expect that the poem's fifth millennium setting would lead Daley to make the present over in the image of the classical past; and indeed his invocation of the mummy carries clear topical allusions to the archaeological finds made in the 1890s by British Egyptologists such as Flinders Petrie. But Daley's satire leads him more consistently into a mirthful, mock-heroic use of the idiom of Saxonist medievalism, and hence the poem's historical vision is an oblique but undeniable instance of border Anglo-Saxonism. Indeed, perhaps its significance also lies in its exposure of yet another of AngloSaxonism's unstable discursive borders-a border where high seriousness and satire strike an uneasy coexistence, simultaneously upholding and deflating the nostalgia and the historical grandiosity of its most cherished myths. 
As its central archaeological trope suggests, "An Australian Mummy" is deeply interested in the act of cultural and poetic excavation, and with the eloquence of the apparently "silent" fossil for the sensitive interpreter. But through the voice of Mudlarque, Daley takes mischievous pleasure in exploring the potential in this process for well-meaning blunders to result from the poet-historian's desire for a particular past. While this poem cannot be said to be in any direct dialogue with British Saxonists such as Barnes, it is significant that it dramatizes the historical gaffes perpetrated specifically by the poet who ventures into the territory of romantic cultural archaeology. As Daley's nineteenth-century readers could see, Mudlarque misconstrues the fossil, and puts the fragments of the past together incorrectly, to service a wildly inaccurate, nostalgic perception of the deep Anglo-Australian past.

Contemplating the mummy, Mudlarque is drawn into an idealistic retrospective fantasy in which late nineteenth-century Victoria is conjured up as a pre-modern paradise strongly reminiscent of William Morris's 1888 medievalist time-travel fantasy A Dream of John Ball, in which colonial landowners, as well-loved "Monarchs of the Land," extend benevolence toward their contented workers and hospitality toward travelers. This exaggerated idyll would have been risible to the Bulletin's readers, many of whom had been experiencing the throes of a grave economic depression that lasted through the 1890s, especially in the southeastern colonies, and most particularly in Victoria. The collapse of a number of major banks, including the Federal Bank in 1893, led to the widespread liquidation of businesses and, hence, to severe job shortages. As recorded by the artists and writers of the decade, many of the unemployed were forced to drift through the countryside in search of work, only to be refused shelter and food by members of the ruling landed class, known as the squattocracy. ${ }^{38}$ Mudlarque's Morrisesque medievalist fantasy of agrarian harmony reads, furthermore, as Daley's tongue-in-cheek allusion to the acrimonious shearers' strikes that in the early 1890s had convulsed Australia's most important rural industry. The particularly Whiggish Anglo-Saxonist complexion of Mudlarque's medieval nineteenth century becomes apparent in his reconstruction of Australia's notoriously turbulent colonial parliaments in the romantic image of the Saxon folkmoot. Daley's readers, who looked forward to the replacement of colonial governments by a federal parliamentary system, would have been amused by Mudlarque's absurd misapplication of the "majestic Witenagemote," with all of its romantic connotations of Saxon justice and egalitarianism, to what they saw as their own unrepresentative and corrupt political system.

The effect for the reader is twofold satire. Not only does Daley's Melbourne fall woefully short of Mudlarque's Anglo-Saxonist dream: the dream itself, it is hinted, is ridiculously idealistic. By opening an ironic gap between the actual conditions of his times and Mudlarque's laughably rosy 
misapprehension, Daley offers not only a critique of 1890s Melbourne but also, importantly, a local parody of the popular Victorian fantasy of "merrie" medieval England as a pre-industrial Eden of egalitarianism and unalienated labor. The poem suggests, performatively rather than verbally, that just as colonial Melbourne is far from the Anglo-Saxon ideal imagined by $\mathrm{Mu}-$ dlarque, so too the Anglo-Saxon past would not have been as those in the nineteenth century would wish it to have been. In this respect it comes closer to Mark Twain's satiric critique of medievalist idealism in A Connecticut Yankee in King Arthur's Court (1889), and even closer to the view of Daley's Australian contemporary Joseph Furphy, who at the time Daley's poem appeared was independently formulating his own rejection of the "Norman Yoke" thesis and its fantasy of preconquest Anglo-Saxon egalitarianism and free political institutions. Furphy's critique, which corrects Anglo-Saxonist enthusiasts by reminding them of that society's system of thralldom, was originally intended to be a chapter in his protomodernist masterpiece Such Is Life (1901), but it eventually appeared in his 1906 serialized novel Rigby's Romance. Together these texts present an important satiric countertradition that exposes from within the self-serving agenda underlying Anglo-Saxonist nostalgia, issuing a double-barreled corrective to its elevation of the present via an idealized and apologistic representation of "Old English" society.

Returning to the excavated mummy that is the pretext for the poem, we see that Daley's treatment of it also satirizes the popular Anglo-Saxonizing of the Australian past. Mudlarque opens his paean to colonial Anglo-Australia with an apostrophe to the mummy that makes straight-faced use of the wellworn tropes of Anglo-Saxon migration. By addressing the corpse as "Relic of a Man / Who lived when Austral history began / ... When bold forefathers of the Austral Race... from Northern lands their wondrous voyage took / Led by their tutelary sea-god, Cook!" Mudlarque indulges in a ludicrous version of the already overblown Anglo-Saxonist settler rhetoric epitomized by Rolf Boldrewood's 1890 novel The Miner's Right: A Tale of the Australian Goldfields (1890), where Sydney Cove is described as "that picturesque city which the sea-roving Anglo-Saxon has reared on the strand of the peerless Haven of the South." 39

The "border" nature of this Anglo-Saxonizing of the mummy emerges more sharply when considered within the context of the emerging colonial interest in excavating and collecting the traces of Indigenous Australian culture. While professional archaeological excavation of Aboriginal sites was three decades off at the time Daley wrote his poem, numerous amateur ethnologists were, according to historian Tom Griffiths, avidly collecting, swapping, and exhibiting evidence of the so-called "timeless" culture of Australia's first inhabitants. ${ }^{40}$ Taken in this light, the poem appears-in an opposing gesture to Scott's opening description-to be using the 
mummy to overwrite the traces of Aboriginal "deep time" with a fantasized Anglo-Saxon history in Australia. But the mummy is a more complex relic than this. It is arresting that Mudlarque bookends his reverie with an apostrophe that begins with the invocation "Brown, shrivelled Mummy!" and a valediction that bids the "Brown, weary mummy" to "rest in peace once more!" It is not in itself remarkable that Daley, or Mudlarque, might think of mummified bodies as brown; but the description is a highly charged one in a poem that is otherwise dedicated to rendering the mummy ethnically intelligible as an ancient Anglo-Australian. The poem never explicitly suggests that the excavated mummy is Aboriginal; yet an ambiguity is allowed to emerge. Through the two prominently placed uses of the word "brown," the mummy and the poem become haunted by the specter of a past that $\mathrm{Mu}$ dlarque cannot, or will not, include in his reverie of white-settler AngloAustralia. The mummy becomes a volatile border fossil, able to be claimed by the competing antiquities of Indigenous and Anglo-Saxon Australia. Read this way, a whole series of linguistic instabilities open up: the fact that the mummy "lived when" the great "Northern" migration took place does not mean it took part in them; even the word "Australian" in "Australian mummy" becomes undecidable as a word which, Patrick Wolfe has shown, was used in the 1890s to designate both settler and Indigenous Australians. ${ }^{41}$ But Mudlarque appears oblivious of his own parapraxes as he inserts the mummy firmly into Anglo-Saxon Australia. Daley's poem can thus be seen to be satirically exposing through Mudlarque the historical strategies used by Australian settlers in their attempt to lay a competing historical claim to the land. In so doing, it implicates Anglo-Saxonism within a widespread project of historical denial in relation to prior Aboriginal possession. Reading "An Australian Mummy" in this way, Daley's critique of AngloSaxonism can be seen to be a prescient rehearsal of Tom Griffith's idea that "the Great Australian Silence" on Indigenous dispossession has been less a silence than a "white noise" that has "consisted of an obscuring and overlaying din of history-making." The Anglocentric historicization of Australian culture, Griffith suggests, was part of the British settlers' "attempt to foster emotional possession of the land" despite its being already occupied. ${ }^{42}$

Lest Daley's poem seems to offer a comprehensive dismissal of AngloSaxonist desire under the star of postcolonialism avant la lettre, a vital point of dissonance can be identified in its intriguingly unstable treatment of the retrieved artifacts of poetic tradition. On first analysis, the poem seems to come down against the hubristic fantasy of nineteenth-century Australian ur-poets. Daley's audience, familiar with the campaign to "bardify" Adam Lindsay Gordon, is invited to laugh at the poet-antiquarian Mudlarque's retrospective assessment of Gordon's legacy to Australian verse. In a humorous distinction from Robb's image of Gordon as future ancestral 
monument, for Mudlarque Gordon's work-and indeed all late nineteenthcentury Australian poetry-is an irretrievably lost corpus. Looking back at colonial Australia, he claims:

Poets they have; long perished is their fame.

Their Gordon Kendall is to us a name,

And nothing more....

.................

Long ere the land to nationhood upsprang

Its magic and its mystery they sang,

And hoped for Fame Immortal. Well away!

The tongue they sang in is as dead as they.

Recalling Kendall's respectful portrayal of Gordon the Bard, we can appreciate the sly humor in Daley's reference to "Gordon Kendall" as the principle poet of Australia's "Golden Prime of Poesy." On the one hand a joke on the inaccuracies committed by antiquarians in their misguided efforts to recover ancestral bards, this bundling together of Gordon and Kendall into one long-vanished poet also consigns them equally to posthumous fragmentation. Daley also (in a more accurate prophesy) condemns his own work to oblivion: he is among the unnamed "rest" who "in silence sleep," their work lost forever to later generations of Australian readers. Far from presenting the poetry of his own era, and especially Gordon's work, as expressing a foundational "Anglo-Saxon" moment in Australian literature, Daley envisages a future society in which this early verse has long passed into irrelevance.

Of particular significance in this respect is Mudlarque's description of the language in which the poets have written as a "dead tongue." Here Daley appears to be implying that the English poetic tradition will die out in Australia. Considering the time Daley is writing, this is an audacious prophesy, as it forecasts for Anglo-Australian literature the same social-Darwinist fate popularly predicted for Indigenous Australian culture, which was widely believed by settler colonists to be heading toward its natural demise. ${ }^{43}$ The settlers' self-serving belief in the inevitable decline of "primitive" cultures is turned against them. This sense of linguistic discontinuity with both the mummy and the Anglo-Australian primal poets appears to place Mudlarque at direct odds with Barnes's Saxonist ideology, as well as with Anglo-Saxonist archaeologist and excavational poet William Wylie. In Wylie's poem "The Saxon Chieftain," the poet-archaeologist's contemplation of the corpse of an Anglo-Saxon warrior leads him to meditate on the tongue they share:

Though ages on their winged flight have roll'd, Since on life's scene thou play'dst thy pageant part, Still sounds the Saxon tongue as erst of old, In Saxon breasts still beats the Saxon heart. God bless'd the empire-tree which thou didst plant, And still will bless, and mighty increase grant. ${ }^{44}$ 
This assertion of transhistorical (and transimperial) linguistic continuity is denied by Daley's poet. But, considered closely, things are again more complex: for there is a clear discrepancy between what Mudlarque says and what he does. In denying the survival of the Anglo-Australian tongue he is caught in a performative contradiction, as he himself writes in the language he is declaring dead-and, moreover, in a poetic idiom that has remained unchanged across the three millennia between 1897 and 4897. Again, then, the biases of the would-be poet-archaeologist are exposed; while elsewhere he has been overzealous in claiming links to Anglo-Saxon racial forebears and political antecedents, here he is shown to be too hasty in consigning to fossildom the English language. It could be that the contradiction between Mudlarque's words and practice is simply a side effect of the poem's hasty production; but even if this is so, it points to the serious challenge a postAnglophone Australian poetry presents to Daley's imagination. Indeed, the fact that Mudlarque uses words such as "Witenagemote" in 4897 attests to the survival not just of "Gordon Kendall"'s language, but of the AngloSaxon word hoard. In so many ways this facetious poem could not be more different from the learned, philologically textured work of Barnes; but what it shares with him is a faith in the English language as the one truly unshakeable Anglo-Saxon legacy in Australian culture. Individual aspirants to "fame immortal" may fall into oblivion, but the language lives on beyond them, thriving at the borders of time and space.

What Daley's poem shows is that as Anglo-Saxonism expanded its borders to the farthest reaches of the globe, and implanted itself shallowly in soil where older fossils lay deep, its forms became increasingly eclectic and strained, leaning unsteadily toward satire by the century's end. Yet this is no mere colonial eccentricity; rather, as we have been arguing, it is exemplary of nineteenth-century border Anglo-Saxonism as a discourse in which the search for an Anglo ur-culture ultimately unearthed a history of impurity and volatility. These writers' shared tribute to ethnic-linguistic survival and regeneration, far from being a facile celebration of unadulterated Englishness, bore witness to the dynamic pattern of imperial incursion, cultural cohabitation, and cultural displacement that is the abiding truth of British history.

\section{Notes}

The authors wish to acknowledge the support of the Australian Academy of Humanities and the British Council for their support of the project "Fossil and Root: A Comparative Study of Anglo-Saxonism in Nineteenth-Century British and Australian Poetry" through the Special Joint Project grant scheme. 
1. John M. Graham, "National Identity and the Politics of Publishing the Troubadours," in Medievalism and the Modernist Temper, ed. R. Howard Bloch and Stephen G. Nichols (Baltimore, 1996), 75.

2. Reginald Horsman, Race and Manifest Destiny: The Origins of American Racial Anglo-Saxonism (Cambridge, MA, 1981); Hugh A. MacDougall, Racial Myth in English History: Trojans, Teutons and Anglo-Saxons (Montreal, 1982), 29-124; Clare A. Simmons, Reversing the Conquest: History and Myth in Nineteenth-Century British Literature (New Brunswick, NJ, 1990).

3. Walter Scott, Ivanhoe: A Romance, 3 vols. (Edinburgh, 1820). The title page attributes authorship to "The Author of Waverley," and actual publication was 1819. For a modern critical edition, see Walter Scott, Ivanhoe, ed. Ian Duncan (Oxford, 1996). References in this article will be given both to the original publication and to this standard scholarly edition. Ivanhoe's first edition sold its run of 10,000 copies in less than a fortnight; John Sutherland, The Life of Walter Scott: A Critical Biography (Oxford, 1995), 235. Countless sequels, parodies, and imitations also testify to the novel's success in the popular imagination, from John Beale, The Crusader's Return: A Romance, from Ivanhoe (London, [1820]), to Sir Arthur Sullivan's 1891 opera Ivanhoe, which ran for 155 performances in its first run: Gilbert and Sullivan archive, accessed 18 August 2011, http://diamond.boisestate.edu/gas/sullivan/ivanhoe/ivanhoe_home.html. For the novel's intellectual influence, see Simmons, Reversing the Conquest, $76-112$.

4. Scott, Ivanhoe, 1:7-8; Scott, Ivanhoe, ed. Duncan, 27-28.

5. Scott, Ivanhoe, 1:18-28; Scott, Ivanhoe, ed. Duncan, 33-37 (for a similar point about the setting of the novel, see the Duncan edition, xiii).

6. Sutherland, Life of Walter Scott, 154-57.

7. Richard Fawcett and Richard Oram, Melrose Abbey (Stroud, UK, 2004), 7-8; Aneirin, Y Gododdin: Britain's Oldest Heroic Poem, ed. A. O. H. Jarman (Llandysul, UK, 1990).

8. Scott, Ivanhoe, 1:9; Scott, Ivanhoe, ed. Duncan, 29.

9. Scott, Ivanhoe, 1:vi; Scott, Ivanhoe, ed. Duncan, 14.

10. Thomas Percy, ed., Reliques of Ancient English Poetry, 3rd ed., 3 vols. (London, 1775), 3:vi-xxxix; Sharon Turner, The History of the Anglo-Saxons, 6th ed. (London, 1826), 2:262. For Scott on Turner, see H. J. Grierson, ed., The Letters of Sir Walter Scott, 1787-1807, 12 vols. (London, 1932-1937), 1:221-22 and 12:270.

11. For another reflex of Anglo-Saxonism by a Scottish Borderer, in which violence during the Anglo-Saxon period is depicted as having been necessary so that "a peacefully coöperating England may arise," see Thomas Carlyle, Past and Present (London, 1843), 17 and 261-65.

12. Scott, Ivanhoe, 1:ix-x; Scott, Ivanhoe, ed. Duncan, 15.

13. E.g., in the Edinburgh Monthly Review 3 (1820): 163-99.

14. On Ivanhoe and linguistic chauvinism, see Mary Catherine Davidson, "Remembering Our Saxon Forefathers: Linguistic Nationalism in Ivanhoe," Studies in Medievalism 15 (2006): 41-54. On nineteenth-century Anglo-Saxonism and the desire for linguistic purity more generally, see Clare A. Simmons, "IronWorded Proof': Victorian Identity and the Old English Language," Studies in Medievalism 4 (1992): 202-18.

15. While "Anglo-Saxon" has become the term preferred by modern scholarship, it was common during the nineteenth century to refer to the English before 1066 as Saxons, and their history as "the Saxon past." Barnes used both terms, as well as "Saxon-English" (meaning English before the Conquest). 
16. William Barnes, "Compounds in the English Language," the Gentleman's Magazine 102 (1832): 590.

17. See, for example, the extensive glossary in William Barnes, Poems of Rural Life in the Dorset Dialect (London, 1844), 281-373.

18. William Barnes, The Elements of English Grammar, with a Set of Questions and Exercises (London, 1842), iii-iv.

19. Barnes did make this connection elsewhere in his writings: Early England and the Saxon-English (London, 1869), 1. For discussion of other writers on this topic, see MacDougall, Racial Myth, 89-103 and 119-24, and Simmons, Reversing the Conquest, 71-73, arguing that Thomas Arnold was largely responsible for spreading this ideology.

20. William Barnes, An Outline of English Speech-Craft (London, 1878), and An Outline of Rede-Craft (Logic) with English Wording (London, 1880), throughout.

21. Barnes, Rede-Craft, vi-vii. For a contemporary analogue, see the wiki "The Anglish Moot," http://anglish.wikia.com/wiki/Headside.

22. Barnes, Poems of Rural Life in the Dorset Dialect, 44-46; William Barnes, Hwomely Rhymes: A Second Collection of Rhymes in the Dorset Dialect (London, 1859), 99-100 and 104; William Barnes, Poems of Rural Life in Common English (London, 1868), 3-4.

23. Barnes, Hwomely Rhymes, 3-4; William Barnes, Poems of Rural Life in the Dorset Dialect: Third Collection, 2d ed. (London, 1869), 10-11.

24. William Barnes, "The Dialect of Dorsetshire Compared with the Anglo-Saxon," the Gentleman's Magazine, n.s., 13 (1840): 33-35. Also A Glossary of the Dorset Dialect with a Grammar of Its Word Shapening and Wording (Dorset, 1886), 42.

25. Barnes, "The Dialect of Dorsetshire," 33-34. See also the dissertation in Poems of Rural Life in the Dorset Dialect, 1-37, which makes further claims about close grammatical correspondences between Anglo-Saxon and Dorsetshire not shared with Standard English, such as the Dorset pronoun "en" being the survival of the Anglo-Saxon accusative masculine pronoun "hine."

26. See Malcolm Gillies, "Percy Grainger's Word Games," Meanjin 64 (2005): 14551, and Amanda Harris, "The Nature of Nordicism: Grainger's 'Blue-Gold-RosyRace' and His Music," Australian Musicology 23 (2000): 19-48.

27. "Prolific Australia: The Continent of the British Race," the Lone Hand (1907): 68.

28. Douglas Cole, “The Crimson Thread of Kinship': Ethnic Ideas in Australia, 1870-1914," Historical Studies 14 (1971): 522.

29. See Louise D'Arcens, "Inverse Invasions: Medievalism and Colonialism in Rolf Boldrewood's A Sydney-Side Saxon," Parergon: Journal of the Australian and New Zealand Association for Medieval and Early Modern Studies 22 (2005): 159-82.

30. Henry Kendall, "The Late Mr A. L. Gordon: In Memoriam," in Adam Lindsay Gordon, Poems (1893; reprint, London, 1920), iii-iv.

31. Percy, Reliques of Ancient English Poetry, 1:xv-xvi; Thomas Warton, A History of English Poetry (London, 1774), lii; Sharon Turner, History of the Anglo-Saxons, 2nd ed. (London, 1807), 2:285-86 and 293; John Josias Conybeare, Illustrations of Anglo-Saxon Poetry (London, 1826), vi.

32. Frank Maldon Robb, ed., Poems of Adam Lindsay Gordon (London, 1912), cxxvii.

33. A. R. Chisholm, foreword to Randolph Hughes, C. J. Brennan: An Essay in Values (Sydney, 1934), 12.

34. P. R. Stephensen, "The Foundations of Culture in Australia" (1935), in The Writer in Australia: A Collection of Literary Documents, 1856 to 1964, ed. John Barnes (Melbourne, 1969), 204-44. 
35. David Matthews, "Marcus Clarke, Gothic, Romance," in Medievalism and the Gothic in Australian Culture, ed. Stephanie Trigg (Turnhout, Belgium, 2005), 4-6.

36. This poem first appeared in the Bulletin 18, no. 914, August 21, 1897, 31. Reprinted in Creeve Roe: Poetry by Victor Daley, ed. Muir Holburn and Marjorie Pizer (Sydney, 1947), 128-32.

37. Frank Molloy, Victor J. Daley: A Life (Sydney, 2004).

38. Among the best known of these are Frederick McCubbin's 1896 painting On the Wallaby Track, featuring a homeless young family camping in the bush, and sections of Joseph Furphy's 1901 novel Such Is Life, which includes among its characters a number of rural itinerants.

39. Rolf Boldrewood, The Miner's Right: A Tale of the Australian Goldfields (London, 1890), 316.

40. Tom Griffith, Hunters and Collectors: The Antiquarian Imagination in Australia (Cambridge, 1996), 4.

41. Patrick Wolfe discusses the use of "Australian" as a word used within ethnography to describe Aboriginal "specimens," in his Settler Colonialism and the Transformation of Anthropology (London, 1999), 30.

42. Griffith, Hunters and Collectors, 4.

43. This contrasts with the Aboriginal ethnographic verse written by settler Australians and discussed by John O'Leary, which engaged in a "salvage project" based on the assumption that Aboriginal culture was dying out, and the role of the sympathetic settler was to "smooth the pillow" of the deathbed. See O'Leary, “'The Life, the Loves, of That Dark Race': The Ethnographic Verse of Mid-Nineteenth-Century Australia," Australian Literary Studies 2 (2007): 3-17.

44. See Howard Williams, "Anglo-Saxonism and Victorian Archaeology: William Wylie's Fairford Graves," Early Medieval Europe 16 (2008): 78. 